Jurnal Keislaman, Vol 3, No 1

\title{
POTENSI ZAKAT SEBAGAI FILANTROPI ISLAM DALAM PEMBERDAYAAN EKONOMI
}

\section{Lia Istifhamah}

\author{
STAI Taruna Surabaya \\ (liaistifhamah@gmail.com)
}

\begin{abstract}
Management of zakat which has been carried out by amil zakat as a whole has not been maximized so that the Islamic symbols have not been able to change the paradigm of society, especially Muslims. What needs to be done more intensely by BAZ / LAZ is the classification and grouping of the target recipients of zakat, namely the mustahiq groups that are suitable for receiving productive zakat and mustahiq which can only be given consumptive zakat (to meet daily needs). So that the implementation of Islamic da'wah through zakat as community economic empowerment can be optimal. The government must as soon as possible to revise the Law on Zakat which includes the procedures for managing Zakat, zakat regulation as a tax deduction, the formation of zakat departments / directorates in synergy with financial institutions / DG Tax.
\end{abstract}

Keywords: Zakat, Islam, Economy

121 | Lia Istifhamah, Potensi Zakat sebagai Filantropi Islam dalam Pemberdayaan

EkonomiP a g e 


\section{A. Pendekatan Pembangunan Nasional}

Model Pembangunan sentralistik yang diadopsi pemerintah Indonesia membawa banyak perubahan baik yang menuju ke arah yang positif berupa peningkatan kesejahteraan, infrastruktur maupun pendapatan perkapita. Akan tetapi, pembangunan yang selama ini dilakukan oleh pemerintah yang mengedepankan aspek pertumbuhan dan cenderung mengesampingkan faktor non ekonomi, menjadikan fondasi pembangunan sangat rapuh. Karena pembangunan hanya diprioritaskan untuk meningkatkan GNP sehingga sumber daya alam dieksplorasi secara massif, demi meraih keuntungan ekonomi sesaat.

Pertumbuhan ekonomi dapat dicapai oleh pemerintah sesuai target akan tetapi efek terembesan kebawah (trickle down effect) tidak terjadi, sehingga tidak ada pemerataan kemakmuran pada seluruh lapisan masyarakat. Tingkat pertumbuhan ekonomi secara nasional secara simultan memunculkan gap, karena pendapatan ekonomi antara kelompok mengengah atas meningkat akan tetapi kelompok masyarakat ekonomi menengah ke bawah, statis pendapatan ekonominya cenderung tidak berubah. Ekses negatif lain dari proses pembangunan tersebut adalah tingginya tingkat ketergantungan, meningkatnya jumlah penduduk miskin. Masalah kemiskinan dan pengangguran merupakan beberapa problematika krusial yang dihadapi oleh negara-negara berkembang dan juga bangsa Indonesia.

Dengan perubahan paradigma pembangunan yang desentralisasi, dan tertuang dalam UU Otonomi Daerah tahun 1999 diharapkan mampu memberi nuansa yang lebih kondusif bagi perbaikan ekonomi rakyat Indonesia. Pendekatan ini mencoba menjadikan pembangunan berbasis pada kebutuhan masyarakat lokal. Sehingga bukan paradigma function follow money akan tetapi money follow function. ${ }^{1}$ Berdasarkan UU otonomi ini pemerintah pusat mengharapkan mampu memunculkan kemandirian lokal, artinya pemerintah daerah dapat melakukan fungsinya sesuai dengan potensi lokal, sesuai keinginan masyarakatnya dan kondisi ekonomi mereka. Jika pendekatan desentralisasi ini berjalan baik, maka akan tercipta pemerataan ataupun distribusi kekuasaan.

Masalah pemberdayaan ekonomi bukan hanya sebagai garapan dari pemerintah akan tetapi banyak elemen yang harus dilibatkan dalam rangka peningkatan kesejahteraan ekonomi rakyat. Hal ini dikarenakan jumlah penduduk miskin di Indonesia cukup tinggi, walaupun telah ada penurunan persentase penduduk miskin akan tetapi fluktuasi naik-turunnya tidak besar, range-nya dari tahun sebelumnya relatif pendek.

\section{B. Aturan Zakat dalam agama Islam}

Sebagai salah satu rukun Islam maka sudah menjadi kewajiban seorang Muslim untuk membayar zakat bila ia sudah memenuhi nisabnya. Allah berfirman dalam surat At- Taubah ayat 103 yang artinya: "Ambillah zakat dari sebagian harta mereka...." Zakat adalah ibadah maliyah ijtima'iyah (ibadah yang berkaitan dengan ekonomi keuangan dan kemasyarakatan) yang mempunyai fungsi penting dalam syari'at Islam. Dalam Alquran Allah SWT banyak menyatakan kewajiban membayar zakat dan memberikan sedekah serta membelanjakan sebagian hartanya di jalan yang diridhai Allah SWT. ${ }^{2}$

\footnotetext{
${ }^{1}$ function follow money adalah keberlangsungan program pembangunan akan dijalankan sesuai dengan kondisi keuangan yang ada. Sedangkan money follow function, model ini berbeda yaitu keuangan/ anggaran pembangunan digunakan sesuai dengan fungsi dan kebutuhan yang sebenarnya.

${ }^{2}$ Sayid Sabiq, Fiqh al-Sunnah (Lebanon: Darul Fikr, 1982), 276.
}

122 |Lia Istifhamah, Potensi Zakat sebagai Filantropi Islam dalam Pemberdayaan

EkonomiP a g e 
Dalam ayat yang lain disebutkan para penerima zakat, yaitu pada Surat At-Taubah ayat 60, yang artinya: "Sesungguhnya zakat-zakat itu, hanyalah untuk orang-orang fakir, orang-orang miskin, pengurus-pengurus zakat, para muallaf yang dibujuk hatinya, untuk (memerdekakan) budak, orang-orang yang berutang, untuk jalan Allah, dan orang-orang yang sedang dalam perjalanan, sebagai sesuatu ketetapan yang diwajibkan Allah; dan Allah Maha Mengetahui lagi Maha Bijaksana." ${ }^{3}$ Dari ayat ini dijelaskan ada 8 kelompok yang berhak menerima zakat yang berhak menerima zakat yaitu: Orang fakir: orang yang amat sengsara hidupnya, tidak mempunyai harta dan tenaga untuk memenuhi penghidupannya. Orang miskin: orang yang tidak cukup penghidupannya dan dalam keadaan kekurangan. Pengurus zakat: orang yang diberi tugas untuk mengumpulkan dan membagikan zakat. Muallaf: orang kafir yang ada harapan masuk Islam dan orang yang baru masuk Islam yang imannya masih lemah. Memerdekakan budak: mencakup juga untuk melepaskan muslim yang ditawan oleh orang-orang kafir. Orang berhutang: orang yang berhutang karena untuk kepentingan yang bukan ma'siat dan tidak sanggup membayarnya. Adapun orang yang berhutang untuk memelihara persatuan umat Islam dibayar hutangnya itu dengan zakat, walaupun ia mampu membayarnya. Pada jalan Allah (sabilillah): yaitu untuk keperluan pertahanan Islam dan kaum muslimin. Di antara mufasirin ada yang berpendapat bahwa fisabilillah itu mencakup juga kepentingankepentingan umum seperti mendirikan sekolah, rumah sakit dan lain-lain. Orang yang sedang dalam perjalanan yang bukan ma'siat mengalami kesengsaraan dalam perjalanannya. $^{4}$

Islam begitu transparan dalam mengatur proses pengelolaan zakat hingga pada pendistribusian zakat kepada kelompok sasaran. ${ }^{5}$ Lembaga yang mengelola zakat disebut amil zakat, di Indonesia badana mil zakat / lembaga amil zakat dikelola oleh pemerintah dan swasta. Berbeda dengan masa khalifah Abu Bakar ataupun umar bin Abdul aziz, zakat dikelola dalam satu pintu pelaksanaan adalah pemerintah.

Model pemberdayaan ekonomi melalui zakat merupakan pengejawantahan dari salah satu prinsip dakwah bil al a'mal. ${ }^{6}$ Ibadah zakat merupakan cerminan dalam komitmen Islam dalam memerangi kesenjangan sosial dan secara konsisten memperjuangkan terciptanya keseimbangan ekonomi antara si kaya dengan si miskin, antara kaum berada dengan kaum papa. Upaya membangun keseimbangan antara muzakki dan mustahiq termanifestasi dalam dua bentuk, yaitu: Pertama, bentuk yang bersifat kewajiban yang bernuansa "top down", dengan atau tanpa kesadaran pada golongan yang telah memenuhi persyaratan tertentu harus mengeluarkan sebagian hartanya untuk mustahiq. Kedua, bentuk yang bersifat sukarela (tathawwu'), yang menekankan adanya kesadaran akan pentingnya solidaritas sosial. Keduanya disyariatkan oleh Islam dalam rangka membangun tatanan sosial masyarakat yang harmonis.

Disamping itu, Zakat merupakan ibadah yang mempunyai dimensi sosial kemasyarakatan, baik bagi pembayarnya (muzakki), maupun bagi penerimanya (mustahiq), di antara manfaat zakat adalah sebagai sarana untuk menghilangkan sifat konsumerisme dan kapitalisme dari suatu kelompok tertentu. Zakat juga dapat

\footnotetext{
${ }^{3}$ al-Qur'a>n, 10 (At-Taubah): 60, “Terjemahan Al Qur'an Adz Dzikr-Versi DEPAG Indonesia”.

${ }^{4}$ Ibnu Taimiyah, Siyasah Syar'iyah, Etika Politik Islam (Surabaya: Risalah Gusti, 1995), 35-36.

${ }^{5}$ Muhyiddin Abdusshomad, Fiqh Tradisionalis, Jawaban pelbagai Persoalan Keagamaan Sehari-hari (Surabaya: Khalista, 2004), 160.

${ }^{6}$ Pendekatan kegiatan dakwah bi al-qaul (bi al-ihsan) dan bi al-af'al (termasuk bi al-khitabah atau bi-al-a'mal). Penjabaran dari kedua kegiatan itu melahirkan empat ragam kegiatan dakwah, yakni pertama tabligh dan ta'lim, kedua irsyad, ketiga tathwir, dan keempat tadbir. Asep Muhyiddin dan Agus Ahmad Safei, Metode Pengembangan Dakwah, (Bandung: Pustaka Setia, 2002), 34.

${ }^{7}$ http://klikpsq.blogspot.com, diakses tanggal 23 januari 2012.
}

123 | Lia Istifhamah, Potensi Zakat sebagai Filantropi Islam dalam Pemberdayaan

EkonomiP a g e 
menumbuhkan kepekaan sosial sekaligus sarana introspeksi dan pendidikan jiwa agar bisa berbagi dengan yang lain, berbuat baik antar sesama dengan membantu memenuhi kebutuhan dasar kelompok masyarakat miskin yang merupakan salah satu penerima zakat. Zakat mampu mendorong masyarakat untuk menciptakan tatanan sosial yang harmonis antara golongan atas dan masyarakat miskin. Sehingga bentuk nyata dari dakwah pengembangan dan pemberdayaan masyarakat Islam adalah dengan menyalurkan zakat sesuai dengan prinsip peningkatan kesejahteraan umat.

Zakat juga bisa sebagai sarana yang melepaskan manusia dari ketergantungan terhadap harta dan akan menumbuhkan sosial awarness para muzakki. Selain sebagai upaya mewujudkan kesejahteraan sosial, zakat juga sebagai pembersih harta seorang muslim. Nilai tambah ketika orang mengeluarkan zakat memang bukan benefit yang bisa langsung dirasakan waktu itu juga, akan tetapi sebagai inverstasi harta orang muslim yang manfaatnya akan bisa dinikmati dalam bentuk pahala.

\section{Zakat: filantropi islam sebagai salah Satu Alternatif Pengurangan Kemiskinan}

Pengelolaan zakat, infaq, shodaqoh dan wakaf secara profesional akan bisa menjadi suatu alternatif program pengurangan angka kemiskinan di Indonesia. Misalnya Badan Amil Zakat yang dikelola oleh pemerintah bisa menjadi salah satu alternatif pilihan umat Islam yang akan menyalurkan hartanya. Dalam wadah BAZ tersebut pengelolaan zakat dapat dikembangkan menjadi program yang terintegrasi dengan program pemberdayaan masyarakat miskin lainnya. Sehingga badan amil zakat bisa melakukan sosialisasi kepada masyarakat untuk bersemangat dalam mengeluarkan hartanya dengan berzakat sekaligus ikut ambil bagian dalam pengentasan kemiskinan. Dinas Pendidikan Kota Surabaya misalnya, berencana untuk melakukan kebijakan pemotongan penghasilan untuk zakat, yang tertuang dalam surat edaran bernomor 466/1260/436.6.4/2009 tertanggal 18 Februari 2009. ${ }^{8}$

Dalam surat yang ditandatangani Kepala Dispendik Surabaya Sahudi itu disebutkan bahwa potongan tersebut dilakukan untuk membayar zakat penghasilan. Besaran pemotongan adalah 2,5 persen dari semua gaji dan tunjangan yang diterima setiap bulan rencana pemotongan berlabel zakat penghasilan, infak, dan sedekah itu dilakukan melalui bendahara gaji, selanjutnya disetor ke Badan Amil Zakat Surabaya. Walaupun kebijakan ini banyak menimbulkan gejolak di kalangan guru, namun ide untuk memanajemen zakat dalam suatu lembaga khusus BAZ telah menjadi salah satu pemikiran eksekutif di pemkot Surabaya.

Karena banyak kasus yang menunjukkan ketidakefektifan penyaluran zakat langsung dari muzakki kepada mustahiq, maka pengelolaan zakat dari suatu lembaga yang terpercaya untuk mengelolah zakat demi pemberdayaan ekonomi umat di anggap penulis sebagai suatu yang urgen agar manfaatnya segera dirasakan umat. Tragedi Zakat Pasuruan misalnya, pada tahun 2008 lalu, berkaitan dengan pembagian zakat oleh keluarga H. Syaikhon Fikri, Desa Purutrejo Purworejo, Pasuruan sebesar Rp. 30.000,-, yang mengakibatkan tewasnya 21 jiwa ibu yang ikut antri dalam pembagian zakat tersebut. ${ }^{9}$

Peristiwa "zakat pembawa maut" ini merupakan salah satu bentuk dari potret kemiskinan yang terjadi di Indonesia. Walaupun jumlah yang diterima tidak seimbang dengan resiko yang mungkin menimpa, para mustahiq cenderung mengabaikan. Karena untuk memenuhi kebutuhan sehari-hari uang Rp. 30.000,- cukup besar untuk mereka. Dengan banyaknya tragedi yang terjadi karena pembagian zakat, menjadikan refleksi

\footnotetext{
${ }^{8}$ Jawa Pos, Dispendik Berencana Memotong Gaji Guru 2,5 Persen Per Bulan, 21 Maret 2009.

${ }^{9}$ http://orgawam.wordpress.com, Tragedi Zakat Pasuruan, diakses 17 September 2012.

124 | Lia Istifhamah, Potensi Zakat sebagai Filantropi Islam dalam Pemberdayaan

EkonomiP a g e
} 
tersendiri pada pemerintah ataupun umat Islam untuk mengoptimalkan kinerja lembaga pengelolah Zakat baik lembaga independen maupun milik pemerintah, sehingga tidak ada lagi tragedi "pembagian zakat" yang memakan korban jiwa akan tetapi menjadi zakat yang membawa berkah.

Pada prinsipnya zakat adalah bentuk pendistribusian atau pemindahan sebagian harta kekayaan suatu umat dati satu tangan ke tangan orang lain (baca: amil) selaku pemegang kuasa untuk mengurus, memelihara dan mengembangkan serta mempergunakannya untuk kemudian di bagikan kepada yang berhak menerima. ${ }^{10}$ Sehingga zakat berfungsi sebagai suatu pengendali kerentanan social ekonomi yang terjadi di masyarakat dan sekaligus sebagai upaya kedermawanan dan kepekaan umat Islam dalam upaya pengentasan kemiskinan.

\section{Dakwah Pemberdayaan Ekonomi melalui Zakat}

Dakwah memiliki makna beragam, namun pada hakekatnya dakwah adalah ajakan kepada yang baik dan mencegah dari yang mungkar sesuai dengan kondisi setempat. ${ }^{11}$ Dan dakwah juga diartikan sebagai proses rekayasa sosial dalam rangka pemberdayaan masyarakat. Jadi peran masyarakat muslim bisa menjadi agent of change dengan melakukan transformasi implementasi perintah/kewajiban dalam Islam yang berdimensi pengembangan sosial, ekonomi kemasyarakatan. Zakat yang merupakan ibadah yang bersentuhan dengan ekonomi sebenarnya potensial untuk di manajeriali oleh kaum muslim sebagai bentuk pemberdayaan ekonomi. Sumber dana tetap dalam zakat cukup potensial untuk membantu membiayai pembangunan umat dan negara. Zakat bisa menjadi tidak efektif dan efisien kalau pengelolaannya hanya ditangani secara individul (muzakki) tanpa pengawasan. Pengendalian, dan pembinaan dari pemerintah. ${ }^{12}$ Dalam rangka mengantisipasi kesalahan dalam penyaluran zakat, maka pemerintah harus mampu memegang peranan penting dalam manajemen zakat.

Pada zaman khalifah Abu Bakar pengelolaan zakat ditangani langsung oleh pemerintah, karena pemerintah memiliki sarana yang lengkap dan memiliki kekuasaan untuk memaksa muslim yang tidak mau berzakat. Dasar hukum yang bisa dijadikan acuan adalah Al Quran surat Attaubah ayat 103 yang artinya: Ambillah sedekah (zakat) dari sebagian harta mereka, dengan sedekah itu kamu bersihkan dan sucikan mereka. Dan yang keduan adalah hadist nabi yang diriwayatkan Bukhari-Muslim dari ibnu abbas, yang artinya: beritahukanlah mereka, bahwa Allah mewajibkan atas mereka zakat yang diambil dari orang-orang kaya mereka, kemudian dikembalikan kepada orang-orang fakir mereka. Hadist tersebut merupakan perintah Nabi kepada Muadz waktu diutus kenegeri Yaman. ${ }^{13}$

Strategi dakwah dalam tradisi keilmuan berkaitan dengan visi dan aksi umat Islam. Zakat bisa termasuk aksi dakwah yang berkaitan dengan pemberdayaan masyarakatan secara langsung. Menurut Jurgen Habermas dakwah merupakan media transformasi teori emansipatoris. ${ }^{14}$ dan dakwa merupakan rekayasa sosial yaitu aksi sosial ekonomi yang dilakukan umat Islam. Implikasi positif ketika pengelolaan zakat

\footnotetext{
${ }^{10}$ Bustami Gain dan Hamdany Ali, Islam sebagai Aqidah dan syariah (Jakarta: bulan bintang, 1968), 33-34.

${ }^{11}$ Sja'roni, Pengantar Studi Islam (Surabaya: IAIN Sunan Ampel Surabaya Press, 2002), 182.

${ }_{12}$ Masjfuk Zuhdi, Masail Fiqhiyah (Jakarta: PT. Toko Gunung Agung, 1994), 230.

${ }^{13}$ Ibid., 231

14 "Artinya sejauh nama dakwah mampu membantu masyarakat untuk mencapai otonomi dan kedewasaan (mundigkeit) berpikir dan bertindak. Masyarakat yang reflektif(cerdas) adalah yang berhasil melakukan komunikasi yang baik dan memuaskan dengan sesama dalam interaksinya”. Dijelaskan jurgen habermas ketika dikukuhkan menjadi guru besar di universitas Frankfurt dalam karya " knowladge and human interest”. (Andy Dermawan dkk, Metodologi Ilmu Dakwah (Yogyakarta: LESFI, 2002), 73.
}

125 | Lia Istifhamah, Potensi Zakat sebagai Filantropi Islam dalam Pemberdayaan

EkonomiP a g e 
dilakukan secara tepat adalah dana zakat bisa menjadi investasi suatu bangsa dalam pertumbuhan ekonomi. Karena menurut Harold-Domar, bahwa investasi adalah aspek utama dalam pembangunan ekonomi dan modernisasi. ${ }^{15}$

Potensi jumlah penerimaan zakat dalam per tahun di Indonesia mencapai Rp19 triliun, data ini menurut keterangan ketua umum Badan Amil Zakat Nasional (Baznas) Prof DR Didin Hafidhuddin ${ }^{16}$. Namun potensi tersebut belum sebanding dengan zakat yang terkumpul dari seluruh Badan Amil Zakat Daerah (Bazda) seluruh Indonesia yang pada 2009 hanya sebesar Rp 900 miliar per tahun. Jumlah pengumpulan zakat Indonesia cukup minim, tidak sebanding dengan potensi yang ada, padahal potensi zakat itu cukup strategis dalam meningkatkan perekonomian dan kesejahteraan masyarakat. Karena zakat merupakan salah satu sarana distribusi pendapatan ekonomi masyarakat.

Secara konseptual, ide pemberdayaan (Empowerment) bersentuhan dengan kekuasaan atau keberdayaan. Pemberdayaan dianggap sebagai sebuah proses yang memungkinkan kalangan individual ataupun kelompok merubah keseimbangan kekuasaan dalam segi sosial, ekonomi maupun politik pada sebuah masyarakat ataupun komunitas. Kegiatan pemberdayaan dapat mengacu pada banyak kegiatan, di antaranya adalah meningkatkan kesadaran akan adanya kekuatan-kekuatan sosial yang menekan orang lain dan juga pada aksi-aksi untuk mengubah pola kekuasaan di masyarakat. Dari jenisnya, pemberdayaan/penguatan dapat dilihat pada dua level, individual dan komunitas. Adapun indikator pemberdayaan menurut Kieffer mencakup tiga dimensi yang meliputi: kopetensi kerakyatan, kemampuan sosiopolitik, dan kompetensi partisipatif. $^{17}$

Pemberdayaan menunjuk pada kemampuan orang, khususnya kelompok rentan dan lemah sehingga mereka memiliki kekuatan atau kemampuan dalam memenuhi kebutuhan dasarnya sehingga mereka memiliki kebebasan (freedom) dan menjangkau sumber-sumber produktif yang memungkinkan untuk meningkatkan pendapatan serta berpartisipasi dalam pembangunan dan keputusan-keputusan yang mempengaruhi mereka. ${ }^{18}$ Pemberdayaan yang dimaksudkan disini adalah pemberdayaan masyarakat miskin melalui pengelolaan zakat secara profesional.

Hasil riset K.A. Ishak dari Oregon University AS pada tahun 2003 mempublikasikan tentang kegagalan lembaga-lembaga pembangunan internasional di dalam mengurangi kemiskinan global. Sehingga, ia pun merekomendasikan perlunya mengadopsi strategi baru dalam memerangi kemiskinan global, khususnya di negaranegara timur tengah dan Afrika. Dalam riset itu pula, Ishak menegaskan bahwa zakat harus dioptimalkan mengingat ia adalah instrumen yang secara tradisional dan kultural dekat dengan kehidupan masyarakat Timteng dan Afrika Utara. ${ }^{19}$ Fenomena di negara-negara Timur tengah maupun Áfrika mungkin bisa dijadikan pijakan untuk mengidentifikasi masalah yang ada di Indonesia (baca: negara dengan jumlah muslim

${ }^{15}$ Arief Budiman, Teori Pembangunan Dunia Ketiga (Jakarta: Gramedia Pustaka Utama, 1995).

${ }^{16}$ http://www.antara.co.id/arc, Potensi Pengumpulan Zakat Capai Rp19-Triliun, diakses tanggal 1 Maret 2012.

${ }^{17}$ indikator kerberdayaan menurut parson, meliputi: pertama, proses pembangunan yang bermula dari pertumbuhan individu yang kemudian berkembang menjadi sebuah perubahan sosial yang lebih besar. Kedua, sebuah keadaan psikologis yang ditandai oleh rasa percaya diri, berguna dan mampu mengendalikan diri dan orang lain. Ketiga, pembebasan yang dihasilkan dari sebuah gerakan sosial, yang dimulai dari pendidikan dan politisasi orang-orang lemah dan kemudian melibatkan upaya-upaya kolektif dari orang-orang lemah tersebut untuk memperoleh kekuasaan dan mengubah struktur-struktur yang masih menekan (parson et.al) (Edi Suharto, Membangun Masyarakat Memberdayakan Rakyat (Bandung: Refika Aditama, 2006), 63.

18 Ibid., 58.

19 http://ppimalaysia.org/Jurnal, Perkuat Peran ZISWAF dalam Pembangunan Nasional, diakses tanggl 20 Maret 2012.

126 | Lia Istifhamah, Potensi Zakat sebagai Filantropi Islam dalam Pemberdayaan

EkonomiP a g e 
terbesar di dunia). Sehingga pengelolaan zakat secara profesional di Indonesia bisa juga menjadi program alternatif untuk mengurangi kemiskinan.

Keberadaan zakat sangat tergantung terhadap keberadaan lembaga zakat yang mengelolanya. Secara yuridis formal keberadaan zakat diatur dalam UU No 38/1999 tentang Pengelolaan Zakat. Lembaga pengelola zakat saat ini tidak hanya dimonopoli oleh BAZIS yang dikelola oleh negara tetapi dikelola secara swadaya oleh masyarakat. Bahkan kecenderungan yang ada masyarakat lebih mempercayai penyaluran zakat mereka kepada lembaga-lembaga amil zakat swasta ataupun langsung ke masjid di dekat rumah mereka.

Ada pemikiran yang menjadikan zakat berperan penting dalam pengembangan masyarakat, ${ }^{20}$ bahwa zakat merupakan pelengkap pendapatan kepada mereka yang tidak mampu mendapatkan pekerjaan yang mencukupi kebutuhannya (mustahiq) sehingga asumsi zakat pada masyarakat umum hanya sebagai charity. Dakwah pemberdayaan ekonomi yang dilakukan melalui zakat bisa dalam bentuk: Pertama, manajemen zakat yang dilakukan dengan bekerjasama antara badan amil zakat independen maupun milik pemerintah dengan bank konvensional maupun syariah yang peduli dengan pemberdayaan ekonomi rakyat serta dengan pemerintah melalui program-program pemberdayaan ekonomi melalui pemberian pinjaman lunak tanpa agunan. Agar adanya sigergisitas antara program-program pemberdayaan ekonomi rakyat dan mengurangi kemiskinan dalam rangka meningkatkan kesejahteraan umat yang berkesesuaian dengan misi zakat.

Kedua, uang zakat bisa dikelola dan dipergunakan oleh badan amil zakat untuk menyediakan pelatihan dan modal dalam bentuk kredit bebas bunga ataupun hibah yang memungkinkan untuk mendirikan usaha-usaha mikro atau usaha kecil bagi mustahiq sebagai pemberdayaan ekonomi. Ketiga, memberikan bantuan pendidikan melalui dana zakat. Dengan meningkatnya pendidikan masyarakat maka akan mudah untuk merubah pola pandang masyarakat dalam melihat kehidupan sosial ekonominya. Keempat, merubah pola pikir dan wawasan mustahiq.

Peningkatan kesadaran wajib zakat bagi umat Islam bukan hal yang mudah akan tetapi yang lebih penting adalah bagaimana perubahan paradigma para penerima zakat yang bukan hanya sebagai orang yang pasrah dan menunggu uluran tangan muzakki untuk memberikan bantuan ekonomi, akan tetapi bagaimana menjadi seorang yang mempunyai visi kemandirian dalam meningkatkan kesejahteraan mereka melalui usaha produktif. Sehingga semangat kewirausahaan akan ada pada diri mustahiq dan keinginan untuk merubah nasib mustahiq menjadi muzakki akan bisa diwujudkan.

Dalam rangka menciptakan kesadaran dan kemandirian penerima zakat, bisa dilakukan badan amil zakat dengan bekerjasama dengan lembaga swadaya masyarakat yang concern pada upaya pendampingan dan pemberdayaan ekonomi, salah satu wujud nyata yang bisa dilakukan adalah dengan melalui pelatihan kewirausahaan, pinjaman lunak mikro ekonomi terpadu dan pengawasan pasca pemberian pinjaman untuk peningkatan kesejahteraan ekonomi.

Dengan beberapa program pemberdayaan ekonomi melalui zakat diharapkan mampu menjadi stimulus bagi para pembayar zakat untuk mengeluarkan sebagaian

\footnotetext{
${ }^{20}$ Pengembangan masyarakat tidak dilihat dari sebagai suatu proses pemberian dari pihak yang memiliki sesuatu kepada pihak yang tidak memiliki . kerangka pemahaman ini akan menjeruskan kepada usaha-usaha yang sekedar memberikan kesenangan sesaat saja dan hanya bersifat tambal sulam. Pemberian bantuan dana segar (fresh money) kepada masyarakat akan mengakibatkan hilangnya kemandirian dalam masyarakat tersebut, atau timbulnya ketergantungan. Akibat yang lebih buruk adalah tumbuhnya mental minta-minta daripada memberi. (Sja'roni, Studi Islam,186).
}

127 | Lia Istifhamah, Potensi Zakat sebagai Filantropi Islam dalam Pemberdayaan

EkonomiP a g e 
hartanya untuk menyucikan harta yang dimiliki sekaligus sebagai bentuk nyata partisipasi pengentasan kemiskinan yang ada di Indonesia.

Dari beberapa model manajemen zakat dalam rangka meningkatkan kesejahteraan dan mengurangi jumlah mustahiq, maka penulis menganggap perlu untuk menginventarisir beberapa alternatif yang bisa dilakukan oleh pemerintah dalam pengelolaan zakat kedepan, yaitu dengan melalukan evaluasi peran dan posisi BAZ/LAZ, melalukan amandemen UU tentang zakat dan melakukan kebijakan pengurangan pajak dengan zakat bagi para wajib zakat.

\section{E. Optimalisasi Peran dan Posisi BAZ/ LAZ}

Sebagai lembaga yang secara khusus menangani zakat Badan Amil Zakat (BAZ) dan Lembaga Amil Zakat (LAZ) nampaknya belum menjadi organisasi yang banyak dipilih masyarakat dalam menyalurkan zakatnya, walaupun sebenarnya lebih aman dan akan tepat sasaran pemberian zakat kepada mustahiq apabila dilakukan oleh lembaga yang menangani zakat, sehingga resiko yang hingga menimbulkan korban jiwa dapat dihindari jika pembagian zakat tidak dilakukan dengan model direct giving oleh muzakki. Akan tetapi, data di lapangan menunjukkan keengganan muzakki menyalurkan zakat pada lembaga zakat. Survei 2007 oleh Pirac menunjukkan bahwa responden yang menyalurkan zakatnya ke BAZ dan LAZ hanya hanya $6 \%$ dan 1,2\%. Sebagian besar responden (59\%) ternyata memilih menyalurkan zakatnya kepada mesjid di sekitar rumah. ${ }^{21}$ Masjid banyak dipilih karena praktis, dekat dengan rumah responden dan juga penerima zakat adalah muzakki di lingkungan sekitar mereka.

Hasil penelitian beberapa lembaga Survey yang mengemukakan bahwa adanya keengganan pemberi zakat menyalurkan zakatnya melalui BAZ/ LAZ, adalah tantangan bagi BAZ/ LAZ untuk menunjukkan eksistensi lembaga kedepan dan mampu membangun image sebagai lembaga yang profesional dan akuntable dalam pengelolaan zakat. Keberhasilan baz/laz menjadi lembaga profesional akan membawa damapak pada tumbuhnya kepercayaan muzakki untuk mau menyalurkan zakat melalui BAZ/ LAZ. Langklah konkrit yang bisa dilakukan Baz/Laz dalam pencitraan lembaga misalnya melalui program penyaluran dan pengelolaan keuangan hasil zakat, infaq dan shodaqoh secara jelas, terukur, dibutuhkan masyarakat, dan lebih fokus pada upaya pemberdayaan ekonomi para mustahiq, sekaligus membangun mentalitas kewirausahaan (entrepreneurship) dan adanya laporan secara transparan kepada publik mengenai pelaksanaan program pemberdayaan ekonomi rakyat melalui dana zakat.

Sesuai dengan misi utama zakat adalah mengubah mustahiq menjadi muzakki sebagai salah satu alternatif pengentasan kemiskinan, maka sistem dan konsep pengelolaan serta pendistribusian zakat ini harus dipahami oleh seluruh pengelola zakat, baik di badan amil zakat (BAZ) yang dibentuk pemerintah maupun lembaga amil zakat (LAZ) yang dibentuk masyarakat. Jika pengurangan angka kemiskinan itu menjadi program secara nasional yang langsung ditangani satu lembaga, maka seluruh zakat mal yang terhimpun wajib disalurkan sebagai zakat produktif.

BAZ/LAZ harus dikelola dengan manajemen zakat yang profesional, dengan melakukan beberapa perbaikan dalam pembagian peran dan tata laksana petugas (amil). Apa yang dilakukan amil selama ini dianggap belum optimal dan belum diimplementasikan secara benar. Implikasinya, para muzakki tidak menaruh kepercayaan pada amil dan mereka cenderung membagi zakatnya sendiri secara langsung kepada para mustahiq, tidak melalui amil.

\footnotetext{
${ }^{21}$ http://www.pirac.org/teliti_ZA.htm, diakses tanggal 20 Maret 2012. 128 | Lia Istifhamah, Potensi Zakat sebagai Filantropi Islam dalam Pemberdayaan 
Amil adalah pengelola zakat yang secara eksplisit disebut Al-Quran. Amil harus bekerja dan mengurus zakat secara benar. Orang-orang yang ditugasi sebagai amil hendaklah yang memiliki kompetensi pemahaman tentang zakat, filosofi, dan tujuannya. Orang-orang yang ditugasi untuk menghimpun zakat mencatat, menginventarisasi mustahiq, mengklasifikasikan/ mengelompokkan mustahiq, mendistribusikannya, dan membuat laporan pertanggungjawaban kepada publik. Segmentasi sasaran yang jelas dan terencana dalam pembagian zakat ini dapat memberikan pengaruh dan menggerakkan kegiatan ekonomi rakyat. Bila simpul-simpul ini dapat berkembang tentu akan mampu menciptakan lapangan kerja yang pada akhirnya mengurangi kemiskinan di daerah sekitarnya.

Dalam rangka optimalisasi pengelolaan zakat, badan amil zakat perlu membangun jaringan dengan lembaga lain yang berkaitan dengan pemberdayaan penerima zakat. Jaringan ini sangat penting guna memperlancar proses distribusi, pembinaan dan pemberdayaan para penerima zakat dalam bentuk modal usaha. Dengan adanya jaringan akan mempermudah untuk mengembangkan usaha dan penyaluran hasil usaha. Pembangunan jaringan ini menjadi tanggung jawab yang sering terabaikan oleh badan pengelola zakat.

Ada empat peran amil, yaitu: Pertama, mengingatkan para muzakki agar tidak lupa membayar kewajiban zakat. Kerja amil zakat adalah menjemput bola mendatangi muzakki (khudz min amwalihim) agar disiplin membayar zakat harta mereka sehingga hartanya bersih, suci, berkah, dan meningkat.

Kedua, menjadi mediator antara mustahiq dan muzakki dalam pendistribusian uang zakat dan model pengelolaannya. Ketiga, mengontrol para mustahiq tidak menerima zakat dari berbagai sumber, yang dapat menimbulkan sifat dan sikap ketergantungan, sehingga kemandirian dan keinginan untuk mengubah nasib dan masa depannya tidak muncul.

Keempat, memilah dan memilih serta mengklasifikasikan mustahiq sehingga jelas di antara mereka mana yang lebih tepat menerima zakat konsumtif dan mana yang seharusnya diberi zakat produktif. Dengan klasifikasi itu, diharapkan dapat ditentukan target per tahun, berapa orang mustahiq yang diprediksi bisa menjadi muzakki sehingga bisa dibina atau dilatih menjadi seorang entrepreneur. Kelima, memberikan pelatihan dan peningkatan performance amil agar kerjanya tepat sasaran serta memberikan reward lepada amil yang berprestasi oleh pemerintah.

Selain merubah paradigma para amil, BAZ/ LAZ juga perlu melakukan riset di lapangan dan memotong jalur yang rumit dari penyaluran zakat melalui badan amil zakat. Kecenderungan pendistribusian zakat secara langsung oleh muzakki kepada mustahiq karena mudah terjangkau dan tepat sasaran (baca: karena muzakki mengetahui tingkat kemampuan ekonomi mustahiq).dalam upaya perbaikan image, ada beberapa hal yang perlu dilakukan antara lain, yaitu: Pertama, sosialisasi yang Terus menerus lepada masyarakat. Kedua, membangun badaya kerja yang profesional dan amanah serta adanya waktu kerja yang full time.

Ketiga, penyaluran yang lebih tepat sasaran dan sesuai dengan syari'ah. Keempat, BAZ/LAZ mengurangi jalur zakat konsumtif dan penyaluran zakat secara langsung, dan memperbanyak pendistribusian zakat produktif diharapkan dapat mengurangi angka kemiskinan secara significan. Kelima, mensinergikan dengan kerja lembaga amil zakat yang lain. Keenam, mempublikasikan hasil audit dari akuntan publik, sehingga masyarakat mngetahui kinerja BAZ/LAZ. 
Menurut Prof Dr Ahmad Rofiq MA, guru besar Fakultas Syariah IAIN Walisongo Semarang. ${ }^{22}$ Menyebutkan beberapa langkah cukup strategis untuk meningkatkan jumlah zakat yang terkumpul jika dijalankan secara optimal. Pertama, penguatan lembaga amil zakat agar transparan dalam menyalurkan dana zakat, sehingga dipercaya publik. Kedua, penyaluran dana zakat itu harus tepat sasaran, bukan hanya untuk kebutuhan konsumtif tetapi juga digunakan untuk usaha produktif seperti pemberian beasiswa dan modal kerja kepada mustahiq. Pada 2009 ini diyakini akan terjadi lonjakan jumlah para muzakki karena pemerintah sudah memiliki kepedulian yang cukup tinggi

\section{F. Amandemen UU tentang Zakat yang lebih progresif}

Misi utama zakat yang disyariatkan adalah mengurangi kemiskinan, yakni mengubah mustahiq menjadi muzakki. Agar pelaksanaan misi zakat tersebut dapat terwujud secara konkret, maka pemerintah harus sesegera mungkin untuk mengamandemen UU No 38 tahun 1999 tentang pengelolaan zakat dengan melibatkan unsur pemerintah dan swasta yaitu: Pertama, Depag, Baznas, Lembaga pengelolah zakat independen dan stakeholder zakat yang lain untuk menyusun draf UU tentang pengelolaan zakat yang lebih kompleks sesuai dengan kebutuhan dan dengan memperhatikan fungsi guna dan tata kelola zakat bagi masyarakat Indonesia dan komunitas muslim pada khususnya. Jika memang dipandang perlu, MUI dapat mengeluarkan fatwa bahwa menyalurkan zakat melalui BAZ/LAZ adalah wajib, sebagai upaya untuk mengoptimalkan kerja badan amil zakat dalam upaya pengentasan kemiskinan dan menjadikan dana zakat sebagai dana produktif pemberdayaan ekonomi umat.

Kedua, sanksi untuk muzakki yang tidak mau mengeluarkan zakat harus disebut tegas dalam UU Zakat. Bentuk sanksi bisa berupa pelayanan untuk kepentingan umum, misalnya pengurusan KTP harus menyertakan bukti nomor wajib zakat. Ketiga, struktur organisasi yang jelas dalam badan amil zakat. Adanya pembagian wilayah kerja antara BAZ maupun LAZ, sehingga perlu diatur pola pengawasan, kordinasi dan distribusi yang berkaitan dengan optimalisasi fungsi dan peran lembaga pengelola zakat.

Keempat, zakat sebagai pengurang pajak. Artinya para muzakki secara otomatis terdaftar sebagai wajib zakat. Dan ketika muzakki sudah mengeluarkan zakat mal-nya sesuai dengan aturan dalam Islam maka secara langsung kewajiban untuk membayar pajak akan terkurangi senilai dengan jumlah pajak yang dikeluarkan. Kelima, fungsi penyaluran dan distribusi zakat dilakukan lembaga khusus dengan berdasar rekomendasi dari BAZ dan pengawasan dari LAZ.

\section{G. Zakat Pengurang Pajak}

Selama ini konsep Zakat dan Pajak masih berdiri sendiri-sendiri. Sasaran akhir dari keduanya adalah pengurangan kemiskinan, distribusi asset dan sebagainya. Jika keduanya tidak dalam satu penangganan maka sasaran akhir itu tidak pernah tercapai secara optimal. Meskipun kedua konsep itu memiliki kerangka filosofi ekonomi tersendiri dimana, zakat dapat dipandang sebagai mekanisme spiritual bermasyarakat melalui sharring ekonomi. Sedangkan pajak adalah kewajiban ekonomi individu dalam kehidupan berbangsa dan bernegara, karena dalam bernegara pajak adalah komponen penting dalam sumber pendapatan dan secara tidak langsung adalah sumber kehdupan ekonomi suatu negara. Untuk meringankan umat Islam dari beban kumulatif berupa

\footnotetext{
${ }^{22} \mathrm{http}: / / \mathrm{www}$. antara.co.id/arc, Potensi Pengumpulan Zakat, diakses tanggal 1 Maret 2012. 130 | Lia Istifhamah, Potensi Zakat sebagai Filantropi Islam dalam Pemberdayaan EkonomiP a g e
} 
zakat dan pajak, maka hendaknya pemerintah memberi dispensasi bagi pembayar Zakat berupa pengurangan pajak. ${ }^{23}$

Dalam wacana hukum, pajak dapat didefinisikan sebagai iuran rakyat kepada kas negara berdasarkan undang-undang (yang dapat dipaksakan) dengan tiada mendapat jasa timbal (kontraprestasi) yang langsung dapat ditunjukkan dan yang digunakan untuk membayar pengeluaran umum. PPh atau Pajak Penghasilan adalah pajak yang dikenakan atas penghasilan berupa gaji, honor/ honorarium, upah, tunjangan dan pembayaran lain yang diterima atau diperoleh Wajib Pajak orang pribadi dalam negeri sehubungan dengan pekerjaan atau jasa, jabatan dan kegiatan. ${ }^{24}$ Adapun subjek PPh adalah orang pribadi; warisan yang belum terbagi sebagai satu kesatuan, menggantikan yang berhak; badan; dan bentuk usaha tetap (BUT).

Ketua Umum Baznas, Didin Hafiduddin, meminta DPR menjadikan zakat sebagai pengurang pajak karena zakat berperan dalam pengentasan kemiskinan. Karena itu, ia meminta DPR segera mengamandemen UU Pajak Penghasilan (PPh). Saat ini, kata Didin, zakat baru ditetapkan sebagai pengurang penghasilan kena pajak (PKP) dan bukan sebagai pengurang langsung atas pajak. Hal tersebut berdasarkan UU No 17 tahun 2000 tentang amandemen atas UU No 7 tahun 1983 tentang pajak penghasilan (PPh) dan UU No 38 tahun 1999 tentang pengelolaan zakat. Kebijakan tersebut dinilai tidak berdampak besar terhadap perkembangan zakat di Indonesia. ${ }^{25}$

Direktur Pemberdayaan Zakat Departemen Agama, Nasrun Haroen mendukung usulan zakat sebagai pengurang pajak. Dikatakan bahwa zakat memiliki peran dan fungsi yang sama dengan pajak dalam mendukung pengentasan kemiskinan. Karena itu, zakat dinilai tepat untuk diusulkan menjadi pengurang pajak. 'Kita sangat mendukung usulan agara zakat menjadi pengurang pajak. ${ }^{26}$ Kebijakan dalam pemerintahan Umar bin Abdul Aziz pernah menerapkan kebijakan ekonomi yang cukup transformatif. Beliau mampu mengelaborasikan antara kewajiban agama bagi muslim untuk membayar zakat dan kewajiban warga negara sebagai individu yang kena pajak untuk kemudian dana tersebut dikelola oleh negara demi kemaslahatan umat dan pengembangan ekonomi masyarakat

Ada kekhawatiran pada sebagian kalangan, bila zakat mengurangi pajak, maka perolehan pajak akan berkurang. Kekhawatiran tersebut tidaklah beralasan. Karena penerimaan zakat tidak akan banyak mengurangi penerimaan pajak, khususnya $\mathrm{PPh}$ Pasal 21 (pajak penghasilan), karena perbedaan tarif pajak yang 30 persen dengan tarif zakat yang relatif sangat rendah yaitu 2.5 persen. ${ }^{27}$ Sehingga pengurangan penerimaan pajak adalah senilai $2,5 \%$ dari total penerimaan pajak pasal 21 sebesar $30 \%$, yaitu hanya 0,75 dari total perolehan pajak PPh 21.

Di Malaysia misalnya, zakat tidak memberikan implikasi negatif bagi perolehan pajak. Akan tetapi yang terjadi adalah efek positif yaitu ditandai dengan semakin tingginya jumlah zakat berpengaruh secara linier dengan jumlah pajak yang masuk dalam pemerintah malaysia. Ini bisa dilihat dalam tabel berikut:

Tabel: Pendapatan Zakat dan Pajak Malaysia (dalam ringgit)

\begin{tabular}{|c|c|c|c|}
\hline Tahun & Zakat & Pajak & Prosentase Zakat terhadap Pajak \\
\hline 2001 & 321 juta & 79.57 milyar & 0.40 \\
\hline
\end{tabular}

\footnotetext{
${ }^{23}$ Zuhdi, Masail Fiqhiyah, 239.

${ }^{24}$ http://organisasi.org, Pengertian Arti Definisi Pajak Penghasilan Karyawan Pasal 21: Pph 21 Penjelasan Tarif Pajak Ptkp Pihak Obyek Subyek, Dll, diakses tanggal 15 Maret 2012.

${ }^{25}$ http://beritazakat.wordpress.com, Zakat Diminta Jadi Pengurang Pph, diakses tanggal 1 April 2012.

${ }^{26}$ Ibid.

${ }^{27} \mathrm{http} / / / \mathrm{www}$.ortax.org/ortax/?mod=berita\&page=show\&id=50\&q=pengurang\&hlm=37, diakses tanggal 1 April 2012.
}

131 | Lia Istifhamah, Potensi Zakat sebagai Filantropi Islam dalam Pemberdayaan

EkonomiP a g e 


\begin{tabular}{|l|l|l|l|}
2002 & 374 juta & 83.52 milyar & 0.45 \\
\hline 2003 & 408 juta & 92.61 milyar & 0.44 \\
\hline 2004 & 473 juta & 99.40 milyar & 0.48 \\
\hline 2005 & 573 juta & 106.30 milyar & 0.54 \\
\hline
\end{tabular}

Sumber: http://ppimalaysia.org/Jurnal/Perkuat-Peran-ZISWAF-dalam-Pembangunan-Nasional.html

Berdasarkan data tersebut menunjukkan keberhasilan pemerintah Malaysia yang menerapkan sistem zakat sebagai pengurang pajak. Dengan sistem seperti ini akan dapat mendorong seorang muzakki untuk aktif membayar zakat karena kewajiban dalam pembayaran pajaknya telah terkurangi dengan tertunaikannya kewajiban membayar zakatnya. Dan adanya penurunan angka kemiskinan di malaysia, serta yang tidak kalah pentingnya adalah jarak pendapatan ekonomi antara kelompok muzakki dan mustahiq tidak terlalu tinggi.

Apabila pemerintah Indonesia berkeinginan untuk melakukan kebijakan zakat sebagai pengurang pajak maka harus ada kesepakatan bersama antara Depag, Ditjen Pajak, Baznas, LSM, DPR dan stakeholders yang lain untuk menyusun blue print tentang rencana kebijakan tersebut. Sehingga tidak adanya timpang tindih dalam penerapannya nanti.

\section{H. Kesimpulan}

Secara singkat dapat diambil kesimpulan, bahwa pengelolaan zakat yang selama ini telah dilakukan oleh badan amil zakat secara keseluruhan belum maksimal sehingga syiar Islamnya pun belum mampu melakukan perubahan paradigma masyarakat khususnya umat Islam. Akan tetapi BAZNAS maupun BAZDA telah berusaha melakukan perbaikan-perbaikan guna menunjang kinerja lembaga agar misi zakat tercipta, kesejahteraan ekonomi umat terwujud dan tingkat kemiskinan menurun.

Upaya-upaya yang telah dilakukan oleh BAZ/ LAZ dalam membangun kepercayaan muzakki adalah dengan melakukan audit oleh akuntan publik sehingga profesionalisme lembaga di ketahui oleh khalayak umum, dan pengelolaan zakat dapat dilakukan secara profesional dan akuntable.

Yang perlu dilakukan lebih intens oleh BAZ/ LAZ adalah klasifikasi dan pengelompokan sasaran penerima zakat, yaitu kelompok mustahiq yang sesuai untuk menerima zakat produktif dan mustahiq yang hanya bisa diberi zakat konsumtif (untuk memenuhi kebutuhan sehari-hari). Sehingga implementasi dari dakwah Islam melalui zakat sebagai pemberdayaan ekonomi masyarakat bisa optimal.

Konsep pengembangan kewirausahaan dan penciptaan muzakki baru melalui pembinaan dan distribusi zakat kepada mustahiq. Dan mengelola dana zakat menjadi dana abadi yang dapat berkembang sehingga dana zakat tersebut tidak habis tetapi memiliki kontinuitas dan menjadi program yang berkelanjutan.

Pemerintah harus sesegera mungkin untuk melakukan revisi UU tentang Zakat yang mencakup prosedur pengelolaan Zakat, regulasi zakat sebagai pengurang pajak, pembentukkan departemen/ direktorat zakat yang bersinergi dengan lembaga keuangan/ Ditjen Pajak. Dan strategi distribusi dan manajerial, sanksi maupun sosialisasi pada peningkatan kesadaran untuk muzakki maupun mustahiq. Dengan demikian zakat bisa menjadi distribusi umat Islam dalam upaya pemberdayaan ekonomi rakyat di Indonesia.

\section{Daftar Pustaka}

Abdusshomad, Muhyiddin. Fiqh Tradisionalis, Jawaban Pelbagai Persoalan Keagamaan Sehari-hari. Surabaya: Khalista, 2004. 132 | Lia Istifhamah, Potensi Zakat sebagai Filantropi Islam dalam Pemberdayaan 
Budiman, Arief. Teori Pembangunan Dunia Ketiga. Jakarta: Gramedia Pustaka Utama, 1995.

Dermawan, Andy. Metodologi Ilmu Dakwah. Yogyakarta: LESFI, 2002.

Gain, Bustami., dan Hamdany Ali, Islam sebagai Aqidah dan syariah. Jakarta: bulan bintang, 1968.

http://ppimalaysia.org/Jurnal, Perkuat Peran ZISWAF dalam Pembangunan Nasional, diakses tanggl 20 Maret 2012.

http://www.antara.co.id/arc, Potensi Pengumpulan Zakat Capai Rp19-Triliun, diakses tanggal 1 Maret 2012.

http://beritazakat.wordpress.com, Zakat Diminta Jadi Pengurang Pph, diakses tanggal 1 April 2012.

http://klikpsq.blogspot.com, diakses tanggal 23 januari 2012.

http://organisasi.org, Pengertian Arti Definisi Pajak Penghasilan Karyawan Pasal 21: Pph 21 Penjelasan Tarif Pajak Ptkp Pihak Obyek Subyek, Dll, diakses tanggal 15 Maret 2012.

http://orgawam.wordpress.com, Tragedi Zakat Pasuruan, diakses 17 September 2012. http://www.ortax.org/ortax/?mod=berita\&page=show\&id=50\&q=pengurang\&hlm=37 , diakses tanggal 1 April 2012.

http://www.pirac.org/teliti_ZA.htm, diakses tanggal 20 Maret 2012. Maret 2009.

Jawa Pos. "Dispendik Berencana Memotong Gaji Guru 2,5 Persen Per Bulan", 21

Gunawan Sumodiningrat. "Dari Bantuan Langsung Tunai Ke Pemberdayaan" Media Indonesia, 18 Desember 2008.

Majalah ENHA, "Memperkuat Peran Zakat dalam Pembangunan Nasional”, Majalah ENHA, edisi 6 Januari 2009.

Muhyiddin, Asep., dan Agus Ahmad Safei. Metode Pengembangan Dakwah. Bandung: Pustaka Setia, 2002.

Sabiq, Sayid. Fiqh al-Sunnah. Lebanon: Darul Fikr, 1982.

Sja'roni, Pengantar Studi Islam. Surabaya: IAIN Sunan Ampel Surabaya Press, 2002.

Suharto, Edi. Membangun Masyarakat Memberdayakan Rakyat. Bandung: Refika Aditama, 2006.

Taimiyah, Ibnu. Etika Politik Islam, “Terj. Siyasah Syar'iyah”. Surabaya: Risalah Gusti, 1995.

www.bps.go.id/releases/files/kemiskinan, diakses tanggal 1 Maret 2012.

Zuhdi, Masjfuk. Masail Fiqhiyah. Jakarta: PT. Toko Gunung Agung, 1994. 